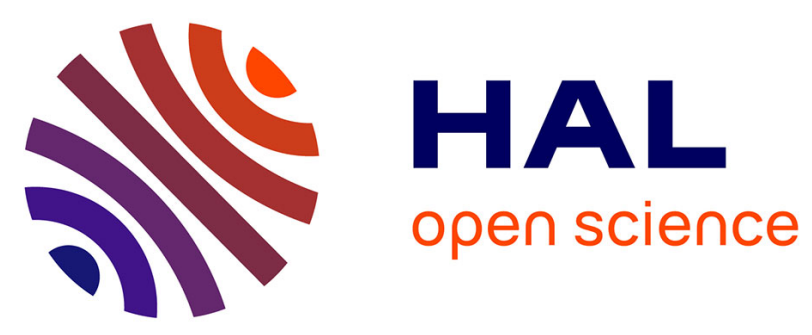

\title{
ESTIMATE OF CARBONYL SULFIDE (OCS) VOLCANIC SOURCE STRENGTH DEDUCED FROM OCS/C02 RATIOS IN VOLCANIC GASES
}

Sauveur Belviso, Ba Cuong Nguyen, Patrick Allard, Ba Cuong Nguyen

\section{- To cite this version:}

Sauveur Belviso, Ba Cuong Nguyen, Patrick Allard, Ba Cuong Nguyen. ESTIMATE OF CARBONYL SULFIDE (OCS) VOLCANIC SOURCE STRENGTH DEDUCED FROM OCS/C02 RATIOS IN VOLCANIC GASES. Geophysical Research Letters, 1986, 13 (2), pp.133-136. 10.1029/GL013i002p00133 . hal-03540430

\author{
HAL Id: hal-03540430 \\ https://hal.science/hal-03540430
}

Submitted on 24 Jan 2022

HAL is a multi-disciplinary open access archive for the deposit and dissemination of scientific research documents, whether they are published or not. The documents may come from teaching and research institutions in France or abroad, or from public or private research centers.
L'archive ouverte pluridisciplinaire HAL, est destinée au dépôt et à la diffusion de documents scientifiques de niveau recherche, publiés ou non, émanant des établissements d'enseignement et de recherche français ou étrangers, des laboratoires publics ou privés. 
GEOPHYSICAL RESEARCH LETTERS, VOL. 13, NO. 1, PAGES 133-136, FEBRUARY 1986

ESTIMATE OF CARBONYI SULFIDE (OCS) VOLCANIC SOURCE STRENGTH DEDUCED FROM OCS/CO2 RATIOS IN VOLCANIC GASES

Sauveur Belviso, Ba Cuong Nguyen, and Patrick Allard

Centre des Faibles Radioactivites, Gif-sur-Yvette, France.

Abstract. Measurements of the concentration ratio of OCS and $\mathrm{CO} 2$ were made in fumaroles of several volcanoes in Italy and Nicaragua. The values obtained, together with previous published data, demonstrate that the OCS/CO2 ratio is positively correlated with the emission temperature of the gases. It ranges from $10^{-7.1}$ to $10^{-2.7}$ at the Vulcano $\left(90^{\circ} \mathrm{C}\right)$ and Erta'Ale $\left(1130^{\circ} \mathrm{C}\right)$ volcanoes, respectively. The global ocs volcanic source strength, deduced from SO2 emission rates, $\mathrm{CO} 2 / \mathrm{SO} 2$ and $\mathrm{OCS} / \mathrm{CO} 2$ ratios in volcanic gases, to estimated to be in the range $6-90 \times 10^{9}$ gocs per year.

\section{Introduction}

Carbonyl oulfide (OCS) is presumed to have an important influence on the global environment, mainly by providing a steady sustained source of sulfur to the stratosphere, sufficient to maintain the sulfate aerosol layer that affects the earth's radiation balance and climate (Crutzen, 1976). For that reason, numerous efforts to quantify its sources and sinks have been conducted. The global sources, Iifetime and mass balance of this species have recently been reviewed by Khalil and Rasmussen (1984). Among the natural ocs sources, volcanoes are considered of minor importance. Estimates of the oCS volcanic contribution, however, still remain uncertain (Cadle, 1980), owing to the small amount of data available on ocs concentration in volcanic gases (Giggenbach and Le Guern, 1976; Allard et al., 1979; Allard, $1980 \mathrm{~b}$; Delorme and Cheminee, 1981) or in plumes of erupting volcanoes. Indeed, the recent eruptions of Mt St Helens (1980) and La Soufrière in St vincent (1979) allowed scientists to obtain the first data on ocs concentration in volcanic plumes (Bandy et al., 1982; Cronn et al., 1982a; Hobbs et al., 1982; Rasmussen et al., 1982; Cronn et al., 1982b).

In order to get a reliable estimate of the ocs volcanic production, we have determined the variability of the OCS/CO2 concentration ratio in gases of various volcanoes. We demonstrate that this ratio closely depends on the emission temperature of the gases within the range $100-1100^{\circ} \mathrm{C}$. From this relationship we can tentatively quantify the ocs volcanic flow, using available data on the $\mathrm{CO} 2 / \mathrm{SO} 2$ ratios of the gases and $\mathrm{SO} 2$ fluxes either estimated or measured by correlation spectrometry.

\section{Experimental}

Four volcanoes have been studied: Momotombo (Nicaragua), Vulcano, Mt C1to and Solfatara of Pouzzoles (Italy). Vulcano belongs to the Aeolian island arc, north of Sicily. Mt Cito is located

Copyright 1986 by the American Geophysical Unton.

Paper number $5 \mathrm{~L} 6747$.

$0094-8276 / 86 / 005 \mathrm{~L}-6747 \$ 03.00$ on the island of Ischia and Solfatara of Pouzzoles is located close to Naples. Gas samples were collected from fumaroles by use of dewar pipes connected with evacuated pyrex bottles $(250 \mathrm{mI})$ equipped with teflon stopcocks. The sampling procedure insured complete recovery of water vapor and gaseous compounds in the bottles. From preliminary tests, sampling bottles filled with an alkaline solution, following the method of Giggenbach (1975), were found inadequate for such a study because ocs tends to react with the solution. The OCS and $\mathrm{CO} 2$ stability in empty bottles was also checked. For this purpose, samples already analysed a few hours after collection were stored for several monthe in the laboratory and then repeatedly analysed. After nine months storage the $0 \mathrm{Cs} / \mathrm{CO} 2$ ratio was found to be at a maximum 50\% lower than the original value. Such a decrease most probably results from the chemical reaction between OCS and SO? favoured by the presence of water, which leads to the formation of atomic sulfur and carbon dfoxide (Fern, 1957). In the case of high temperature volcanic gases with a high $\mathrm{SO} 2$ content, evacuated pyrex bottles filled with magnesium perchlorate were used for sampling in order to remove the water vapor entering the flask and to avoid this decomposition of carbonyl sulfide. The latter procedure appears to be the most suitable to maintain the integrity of the two compounds.

Samples were analysed by gas chromatography. The apparatus consists of a gas chromatograph (HP 5730A) equipped with a flame photometric detector (F.P.D.) and a thermal-conductivity detector (T.C.D.). Separation of OCS from the other sulfur compounds ( $\mathrm{H} 2 \mathrm{~S}, \mathrm{SO}$ ) was done on a $1.80 \mathrm{~m} \times 3.1 \mathrm{~mm}$ $0 . D$. FEP teflon column packed with Chromosil 310 (Supelco), operating 1sothermally at $40^{\circ} \mathrm{C}$, with a $15 \mathrm{ml} / \mathrm{min}$ nitrogen flow rate. $\mathrm{CO} 2$ was separated from the other gaseous compounds ( $\mathrm{Alr}, \mathrm{CH} 4, \mathrm{SO} 2$, H2S) on a $2 \mathrm{~m} \times 3.1 \mathrm{~mm}$ O.D. stainless steel column packed with Porapak QS, maintained 1sothermally at $80^{\circ} \mathrm{C}$ and with a $30 \mathrm{ml} / \mathrm{min}$ helium flow rate.

Samples were injected into the chromatographic columns via an eight port sampling valve equipped with two $0.5 \mathrm{ml}$ sampling loops. Pressure in the loop was measured by using a pressure transducer. standard concentrations of $\mathrm{OCS}$ and $\mathrm{CO} 2$ were supplied by certified gas cylinders (A1r Liquide and Matheson Union Carbide). In this configuration, the lower limit of detection using an $0.5 \mathrm{~m} 1$ sample loop was $0.1 \mathrm{ppmv}$ and $500 \mathrm{ppmv}$ for OCS and $\mathrm{CO2}$, respectively. Molar OCS/CO2 ratios are used in this paper. The accuracy of the $0 \mathrm{CS} / \mathrm{CO2}$ ratios is better than $15 \%$ in most cases.

Results.

The ocs/CO2 ratios we have measured, and those obtained by other authors, are shown in Table 1 . $\overline{\mathrm{R}}$ represents the average molar ocs $/ \mathrm{CO} 2$ ratio at a given temperature for each volcano. This ratio va- 
TABLE 1. Variability of the $\mathrm{OCS} / \mathrm{CO}_{2}$ ratio in gases of various volcanoes

\begin{tabular}{|c|c|c|c|c|c|c|}
\hline Countries & Name of the volcanoes & $\begin{array}{l}\text { Sampling } \\
\text { Year }\end{array}$ & $\begin{array}{l}\text { Temp } \\
\left({ }^{\circ} \mathrm{c}\right)\end{array}$ & $\log \overline{\mathrm{R}}$ & $\begin{array}{l}\text { Range } \\
\text { of } \log \bar{R}\end{array}$ & Source \\
\hline Italy & $\begin{array}{l}\text { Vulcano crater } \\
\text { Vulcano beach } \\
\text { Solfatara of Pouzzoles } \\
\mathrm{M}^{\mathrm{t}} \text { cito }\end{array}$ & $\begin{array}{l}1982 \\
1982 \\
1983 \\
1983\end{array}$ & $\begin{array}{r}290 \\
90 \\
150 \\
100\end{array}$ & $\begin{array}{l}-4.74 \\
-7.10 \\
-6.15 \\
-6.70\end{array}$ & $-(4.80-4.60)$ & $\begin{array}{c}\text { this work } \\
" \\
"\end{array}$ \\
\hline Nicaragua & Momotombo & $\begin{array}{l}1983 \\
1984 \\
1985\end{array}$ & $\begin{array}{l}582 \\
824 \\
862 \\
862\end{array}$ & $\begin{array}{l}-4.10 \\
-3.23 \\
-4.06 \\
-3.71\end{array}$ & $\begin{array}{l}-(4.41-3.79) \\
-(3.41-3.10)\end{array}$ & $\begin{array}{l}" \\
" \\
"\end{array}$ \\
\hline Costa Rica & $\begin{array}{l}\text { Poas } \\
\text { San Cristobal }\end{array}$ & $\begin{array}{l}1981 \\
1981\end{array}$ & $\begin{array}{l}940 \\
525\end{array}$ & $\begin{array}{l}-4.00 \\
-4.10\end{array}$ & & Delorme and Cheminée, 1981 \\
\hline Ethiopia & $\begin{array}{l}\text { Erta'ale } \\
\text { Ardoukoba }\end{array}$ & $\begin{array}{l}1976 \\
1979\end{array}$ & $\begin{array}{l}1130 \\
1070\end{array}$ & $\begin{array}{l}-3.04 \\
-3.88\end{array}$ & $-(3.83-2.69)$ & $\begin{array}{l}\text { Giggenbach and Le Guern, } 1976 \\
\text { Allard et al., } 1979\end{array}$ \\
\hline Indonesia & $\begin{array}{l}\text { Krakatau } \\
\text { Merapi }\end{array}$ & $\begin{array}{l}1980 \\
1978\end{array}$ & $\begin{array}{l}687 \\
900 \\
819 \\
630\end{array}$ & $\begin{array}{l}-3.40 \\
-2.57 \\
-2.62 \\
-4.85\end{array}$ & $-(2.66-2.54)$ & $\begin{array}{c}\text { Allard et al., } 1981 \\
\text { Allard, } 1983 \\
" \\
"\end{array}$ \\
\hline
\end{tabular}

ries between $10^{-7.1}$ at $90^{\circ} \mathrm{C}$ at Vulcano (this work) and $10^{-2} .7$ at $1130^{\circ} \mathrm{C}$ at Erta'Ale (Giggenbach and Le Guern, 1976), 1.e. a range of more than four orders of magnitude. These values appear to depend closely on the temperature of the fumaroles. The decimal logarithms of our own ocs/CO2 ratios, represented by dots, are plotted against the reciprocal of the fumarole temperatures in Figure 1. A linear relationship between $10 \mathrm{~g} \overline{\mathrm{R}}$ and $1 / \mathrm{T}^{\circ} \mathrm{C}$ can be observed, the temperature dependence of $\bar{R}$ being represented by the following equation:

$$
\log \bar{R}=-346.49( \pm 31.08) / T\left({ }^{\circ} \mathrm{C}\right)-3.39( \pm 0.19)
$$

with a correlation coefficient $r^{2}=0.953$ for elght experimental data points. Values between brackets are the standard errors on the coeffictents.

Previous published data are represented of circles in Figure 1. Except those of Merap1, the points fall close to the regression line obtained from our results and fit within its $95 \%$ confidence band limited by the two dashed lines in Figure 1. Therefore, most of the results show that the 0CS/CO2 ratio of volcanic gases is closely related to their emission temperature.

A detailed treatment of the thermodynamical significance of this trend falls beyond the scope of our article. It can be just pointed out that the experimental relationship we observe is consistent with thermodynamical calculations (Heald et al., 1963). Indeed, these show that the ocs/CO2 ratio in a volcanic gas mixture increases with temperature (and with pressure, although less steeply).

\section{Discussion}

The OCS/CO2 values gathered in Table 1 cover nearly the whole range of volcanic gas temperatures $\left(100-1100^{\circ} \mathrm{C}\right)$ and, moreover, encompass the two main types of terrestrial volcanism, i.e. basaltic volcanism in rift zones (Erta'Ale, Ardoukoba) and andesitic-type volcanism in orogenic areas (e.g. Momotombo, Vulcano, Krakatau). Knowing the variability of the $0 \mathrm{CS} / \mathrm{CO} 2$ ratio with temperature and the respective $\mathrm{CO} 2 / \mathrm{SO} 2$ gas ratio and $\mathrm{SO} 2$ fluxes for basaltic and andesitic volcanoes, we can thus evaluate the volcanic contribution to the atmospheric ocs budget. According to Simkin et al. (1981) and Berresheim and
Jaeschke (1983) there are about 520 active volcanoes. 55 volcanoes showed a yearly average of one or more eruptive events for the period 1961-1979 (Berresheim and Jaeschke, 1983), the 465 others remaining in a non eruptive state (Table 2column 8 ).

Calculation of the Eruptive OCS Emissions.

Most erupting volcanoes $(\simeq 50)$ are andesitictype volcanoes located in orogenic areas. The

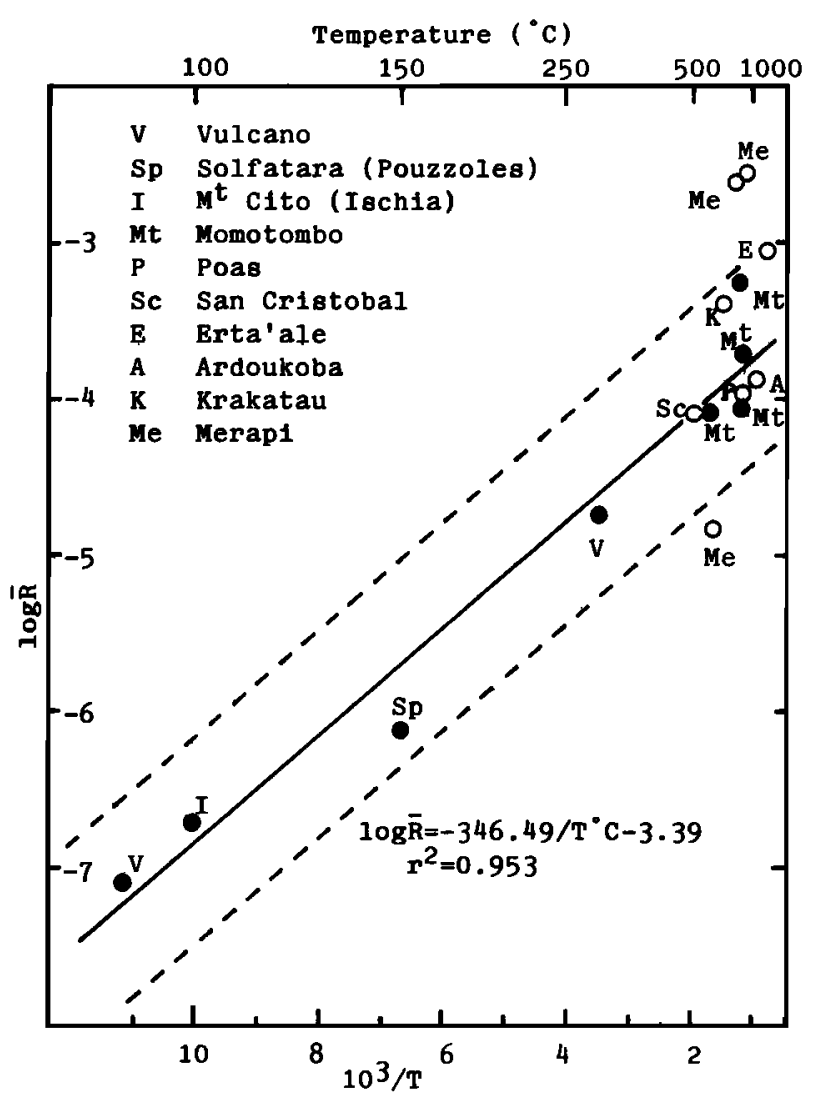

Fig. 1. Logarithm of the average of the ocs $/ \mathrm{CO}_{2}$ ratios $(\log \bar{R})$ plotted against the reciprocal of the emission temperature of the gases $\left(1 / T^{\circ} \mathrm{C}\right)$ Dots refer to our analytical data. Circles refer to prevlously published data. 
TABLE 2. Estimate of the OCS volcanic source strength.

(*) Molar ratio.

\begin{tabular}{|c|c|c|c|c|c|c|c|c|}
\hline $\begin{array}{l}\text { Activity } \\
\text { clasees }\end{array}$ & Categories & $\begin{array}{c}\text { Temperature } \\
\text { range }\left({ }^{\circ} \mathrm{C}\right)\end{array}$ & $\begin{array}{l}\text { OCS } / \mathrm{CO}_{2}^{*} \\
\text { range }\end{array}$ & 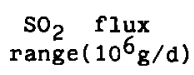 & $\begin{array}{l}\mathrm{CO}_{2} / \mathrm{SO}_{2} \\
\text { range }\end{array}$ & 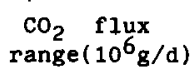 & $\begin{array}{l}\text { Number of } \\
\text { volcanoes }\end{array}$ & $\begin{array}{l}\text { ocs } f \operatorname{lux} \\
\text { range }\left(10^{6} \mathrm{~g} / \mathrm{y}\right)\end{array}$ \\
\hline Eruptive & $\begin{array}{l}\text { Basaltic } \\
\text { Andesitic }\end{array}$ & $\begin{array}{l}900-1100 \\
800-1000\end{array}$ & $\begin{array}{l}1.7 \times 10^{-4}-2.0 \times 10^{-4} \\
1.5 \times 10^{-4}-1.8 \times 10^{-4}\end{array}$ & $\begin{array}{r}1000-4000 \\
300-2000\end{array}$ & $\begin{array}{c}1.2-1.8 \\
4-10\end{array}$ & $\begin{array}{l}825-5000 \\
830-14000\end{array}$ & $\begin{array}{r}5 \\
50\end{array}$ & $\begin{array}{r}350-2500 \\
3000-63000\end{array}$ \\
\hline $\begin{array}{l}\text { Non } \\
\text { eruptive }\end{array}$ & $\begin{array}{c}\text { extra-eruptive } \\
\text { post-eruptive } \\
\text { " }\end{array}$ & $\begin{array}{c}100-400 \\
400-800 \\
11\end{array}$ & $\begin{array}{c}1.4 \times 10^{-7}-5.5 \times 10^{-5} \\
5.5 \times 10^{-5}-1.5 \times 10^{-4} \\
"\end{array}$ & $\begin{array}{r}10 \\
50 \\
275\end{array}$ & $\begin{array}{c}10-20 \\
4-10 \\
\end{array}$ & $\begin{array}{rr}70- & 140 \\
140- & 340 \\
760- & 1900\end{array}$ & $\begin{array}{r}55 \\
100 \\
265 \\
100\end{array}$ & $\begin{array}{r}3350-65500 \\
0-\quad 400 \\
1000-7000 \\
2000-14000\end{array}$ \\
\hline Global & & & & & & & $\begin{array}{l}465 \\
520\end{array}$ & $\begin{array}{r}3000-21400 \\
\times 6500-87000\end{array}$ \\
\hline
\end{tabular}

emission temperature of their gases is usually in the range $800-1000^{\circ} \mathrm{C}$ (Table 2- column 3 ). The remaining 5 volcanoes are of the basaltic-type and are located in regions of most intense basaltic volcanism (Hawaii, Iceland, East Africa, Sicily and Reunion). Their typical emission temperature is in the range $900-1100^{\circ} \mathrm{C}$ (column 3 ), slightly higher than the former. The corresponding OCS/CO2 ratios deduced from equation (1) are shown in Table 2- column 4. Therefore, eruptive ocS emission rates can be assessed from these ratios, from ranges of $\mathrm{SO} 2$ fluxes (column 5) and representative $\mathrm{CO} 2 / \mathrm{SO} 2$ ratios in the corresponding gases (column 6). The sulfur dioxide flux from these two classes of volcanoes have been reviewed by Berresheim and Jaeschke (1983) and Stoiber et al. (1983). Measured SO2 enissions from andesitic-type volcanoes range from about $200 \times 10^{6} \mathrm{~g} / \mathrm{d}$ (e.g. Pacaya) to about $10000 \times 10^{6} \mathrm{~g} / \mathrm{d}(\mathrm{e} . \mathrm{g}$. San Cristobal), but commonly lie between 300 and $2000 \times 10^{6} \mathrm{~g} / \mathrm{d}$ (e.g. Fuego, Santiaguito, Mt St Helens, Merapi). There are comparatively few measured $\mathrm{SO} 2$ flow data for erupting basaltic volcanoes; most are mesurements of the continuous activity of Mt Etna, Sicily. Its $\mathrm{SO}_{2}$ discharge over the period 1975-1985 ranged from 1000 to $12000 \times 10^{6} \mathrm{~g} / \mathrm{d}$, depending on the level of activity, with an average value of about $4000 \times 10^{6} \mathrm{~g} / \mathrm{d}$ (Carbonnelle et al., 1985). This value is taken as an upper limit for the yearly $\mathrm{SO}_{2}$ emission from basaltic volcanoes. It is likely that there are other continental basaltic volcanoes (e.g. Niragongo (East Africa)) that have a SO2 production as high as that of Mt Etna, although measured fluxes are not yet avallable. A lower limit of

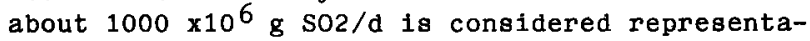
tive of the 502 production from oceanic basaltic valcanoes according to the recent estimate of Gerlach and Graeber (1985) for sustained summit eruptions of Kilauea, Hawail. Consequently, our calculation of the global so2 flux from erupting volcanoes leads to values ranging between 7 and $44 \times 10^{12} \mathrm{~g}$ per year. Such values are higher than those reported by Berresheim and Jaeschke (1983), about $1 \times 10^{12} \mathrm{~g} / \mathrm{y}$, but are considered realistic since they are based on recent $\mathrm{s} 2$ determinations. The $\mathrm{CO2/S02}$ molar ratio in high temperature basaltic gases is typically about $1.5 \pm 0.3$ (Giggenbach and Le Guern, 1976). In these gases nearly all sulfur is in the form of SO2 (Table 2- column 6). The $\mathrm{c} / \mathrm{s}$ ratio in gases from andesitic-type volcanoes tends to be higher, between 2 and 5 (Allard, 1980a; Matsuo et al., 1982; Allard, 1983). In such gases, at $800-900^{\circ} \mathrm{C}$, sulfur is present in the form of both $\mathrm{SO} 2$ and H2S in nearly equal proportions (e.g. Allard, 1980b; Gerlach and Nordlie, 1975).

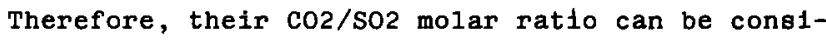
dered to range from about 4 to 10 .

From these different values, the respective $\mathrm{CO} 2$ and consequently the oCS fluxes can be calculated (Table 2- columns 7 \& 9). Estimate of the eruptive OCS emissions ranges from about 3.5 to $65 \times 10^{9} \mathrm{~g}$ per year, the mean being about $30 \times 10^{9} \mathrm{~g}$ per year.

\section{Calculation of the Non Eruptive OCS Emissions.}

Following the classification of Berresheim and Jaeschke (1983), the non-eruptive volcanic activity can be divided into post- and extra-eruptive activity, the corresponding number of volcanoes being 365 and 100 respectively. Post-eruptive activity can last for weeks to years and is characterized by permanent fuming or fumarolic activity at temperatures that remain high, between $400^{\circ} \mathrm{C}$ and $800^{\circ} \mathrm{C}$. Extra-eruptive activity shows exclusively fumarolic and solfataric activity for years to centuries, with low temperature gases $\left(100-400^{\circ} \mathrm{C}\right)$. The corresponding ocs/CO2 ratios are shown in Table 2- column 4. Measured SO2 fluxes from extra-eruptive volcanoes (e.g. Vulcano) are generally around $10 \times 10^{6} \mathrm{~g} / \mathrm{d}$ (Sabroux, 1980). The $\mathrm{C02/SO2}$ ratio in such gases tends to be higher than 10 and can reach 20 (Cioni et al., 1980). About 265 volcanoes in post-eruptive states release an average daily emission of $50 \times 10^{6} \mathrm{~g}$, and $275 \times 10^{6} \mathrm{~g}$ for the other hundred volcanoes. The c02/S02 ratio in post-eruptive high temperature gases has been taken as similar to that in andesitic-type eruptive gares because of the difficulties is estimating the H2S weight in the $\mathrm{c} / \mathrm{S}$ ratio. This tends to rather underestimate the $\mathrm{CO} 2 / \mathrm{SO} 2$ ratio and the ocs flow also.

The results of the calculation show that the ocs extra-eruptive contribution $\left(0-400 \times 10^{6} \mathrm{~g} / \mathrm{y}\right)$ is negligible compared with the post-eruptive one $\left(3-21 \times 10^{9} \mathrm{~g} / \mathrm{y}\right)$.

Hence, one can see from Table 2 that the intensity of the eruptive ocs flow is higher than the non eruptive one. Thus, the global volcanic ocs emission appears to be in the range $6-90 \times 10^{9} \mathrm{~g}$ per year, the mean being $40 \times 10^{9} \mathrm{~g} / \mathrm{y}$. There are few reliable data on the global ocs emissions from volcanoes, since only few measurements have been performed so far (Cadle, 1980). Khal11 and Rasmussen (1984) estimated a global volcanic source strength in the range of $10-50 \times 10^{9}$ gocs/ year based on recent studies of Mt St Helens eruptions. Our own estimate is in accordance with cadle's (1980: $\left.20 \times 10^{9} \mathrm{~g} / \mathrm{y}\right)$ and with the range proposed by Khalil and Rasmussen (1984) in their global mass balance of carbonyl sulfide in the earth's atmosphere. 
Conclusion

Measurements of the OCS/CO2 ratio in gases from various volcanoes have shown that this ratio varies between $10^{-7.1}$ and $10^{-2} \cdot 7$ and is positively correlated with the emission temperature of the volcanic gases. Calculation of the global volcanic ocs source strength based on this relationship, and on $\mathrm{CO} 2$ flows deduced mainly from measured $\mathrm{SO} 2$ fluxes and $\mathrm{CO} 2 / \mathrm{SO} 2$ ratios, leads to the estimate of 6 to $90 \times 10^{9} \mathrm{~g} / \mathrm{y}$. Although our evaluation is based on many assumptions and extrapolations, and needs further development and correction, it confirms the order of magnitude of the ocs volcanic source strength, which is useful for the statement of the atmospheric ocs budget. The ocs volcanic flux represents less than $10 \%$ of the flux of ocs from the oceans to the atmosphere reported by Khalil and Rasmussen (1984).

Acknowledgements. We are grateful to Drs: F. Le Guern, J.C. Sabroux and Mr. D. Tedesco for their help in obtaining volcanic gas samples.

\section{References.}

Allard, P., H. Tázieff and D. Dajlevic, Observation of seafloor spreading in Afar during the november 1978 fissure eruption, Nature, 279, 30-33, 1979.

Allard, P., Composition isotopique du carbone dans les gaz d'un volcan d'arc: le Momotombo (Nicaragua), C. R. Acad. Sc1. Paris, 290, 1525-1528, $1980 \mathrm{a}$.

Allard, P., Proportions des isotopes $13 \mathrm{C}$ et $12 \mathrm{C}$ du carbone émis à haute température par un dome andésitique en cours de croissance: le Merapi (Indonésie), C. R. Acad. Sci. Paris, 291, $613-616,1980 \mathrm{~b}$.

Allard, P., C. Jehanno and J. C. Sabroux, Composition chimique et 1sotoplque des produits solides et gazeux de l'activite eruptive du Krakatau (Indonésie) pendant la periode 19781980 , C. R. Acad. Sc1. Paris, 293, 1095-1098, 1981.

Allard, P., The origin of hydrogen, carbon, sulphur, nitrogen and rare gases in volcanic exhalations: evidence from isotope geochemistry, In Forecasting volcanic events, edited by $H$. Tazieff and J. C. Sabroux, pp. 337-386, Elsevier, Amsterdam, 1983.

Bandy, A. R., P. J. Maroulis, L. A. Wilner and A. L. Torres, Estimates of the fluxes of NO, SO2, H2S, CS2 and COS from Mt. St. Helens deduced from in situ plume concentration measurements, Geophys. Res. Letts., 2, 1097-1100, 1982.

Berresheim, $H$. and $W$. Jaeachke, The contribution of volcanoes to the global atmospheric sulfur budget, J. Geophys. Res., 88, 3732-3740, 1983.

Cadle, R. D., A comparison of volcanic and other fluxes of atmospheric trace gas constituents, Rev. Geophys. Space Phys., 18,746-752, 1980.

Carbonnelle, J., D. Dajlevic, J. Le Bronec, P. Morel, J. C. Obert and P. Zettwoog, Etna: composantes sommitales et parietales des emissions de gaz carbonique. Résultats obtenus pendant la pertode de 1975 a 1984, Note CEA. SPIN/8.3.1. (107), $40 \mathrm{pp}$. , Commissariat à I'Energie Atomique, Gif-sur-Yvette, France, 1985.

Cioni, R., E. Corazza, F. D'Amore and M. Fratta, The Fumaroles of Vulcano (Italy): their chemistry and genesis, paper presented at Workshop on
Volcanic Gases, P.I.R.P.S.E.V., Gif-gur-Yvette, July $3 \& 4,1980$.

Cronn, D. R, and W. Nutmagul, Characterization of trace gases in 1980 volcanic plume of Mt. St. Helens, J. Geophys. Res., 87, 11153-11160, 1982a.

Cronn, D. R. and W. Nutmagul, Volcanic gases in the April 1979 Soufriere eruption, Science, $216,1121-1123,1982 \mathrm{~b}$.

Crutzen, P. J., The possible importance of CSO for the sulfate layer of the stratosphere, Geophys. Res. Letts., 3, 73-76, 1976.

Delorme, H. and J. L. Cheminee, Sean Bull., $\underline{6}$, 1981 .

Fern, J:, The chemistry of carbonyl sulfide, Chem. Rev., 57, 621-640, 1957 .

Gerlach, T. M. and B. E. Nordlle, The $\mathrm{C}-\mathrm{O}-\mathrm{H}-\mathrm{S}$ gaseous system, part $I$ : composition limits and trends in basaltic gases, Am. Jour. Sci., 275, 353-376, 1975.

Gerlach, T. M. and E. J. Graeber, Volatile budget of Kilauea volcano, Nature, 313, 273-277, 1985.

Giggenbach, W. F., A simple method for collection and analysis of volcanic gas samples, Bull. Volcanol., 39, 132-145, 1975.

Giggenbach, W. F. and F. Le Guern, The chemistry of magmatic gases from Erta'Ale, Ethiopia, Geochim. Cosmochim. Acta, 40, 25-30, 1976.

Heald, E. F., J. J. Naughton and I. L. Barnes, Jr., The chemistry of volcanic gases: use of equilibrium calculations in the interpretation of volcanic gases samples, J. Geophys. Res., $68,545-557,1963$.

Hobbs, P. V., J. P. Tuell, D. A. Hegg, L. F. Radke and $M$. W. Eltgroth, Particles and gases in the emissions from the $1980-1981$ volcanic eruptions of Mt. St. Helens, J.Geaphys. Res., 87, 11062-11086, 1982.

Khali1, M. A. K. and R. A. Rasmussen, Global sources, lifetimes and mass balances of carbonyl sulfide ( $\cos )$ and carbon disulfide (CS2) in the earth's atmosphere, Atmos. Environ., 18, $1805-1813,1984$.

Matsuo, S., J. Ossaka, J. Hirabayash1, T. Ozawa and $K$. Kimishima, Chemical nature of volcanic gases of Usu volcano in Japan, Bull. Volcanol., $45,261-266,1982$.

Rasmussen, R. A., M. A. K. Khalil, R. W. Dalluge, S. A. Penkett and $B$. Jones, Carbonyl sulfide and carbon disulfide from eruptions of Mt. St. Helens, Sclence, 215, 665-667, 1982.

Sabroux, J. C., Measurement of the gas discharge at Vulcano (Italy), paper presented at Workshop on Volcanic Gases, P.I.R.P.S.E.V., Gif-surYvette, July $3 \& 4,1980$.

Simkin, T., L. Selbert, L. Mcclelland, W. G. Melson, D. Bridge, C. G. Newhall and J. Latter (Eds), Volcanoes of the world, $232 \mathrm{pp}$. , Hutchinson Ross, New York, 1981.

Stoiber, R. E., L. L. Malinconico and S. N. Williams, Use of the correlation spectrometer at volcanoes, in Forecasting volcanic events, edited by $H$. Tazieff and $J$. C. Sabroux, Elsevier, Amsterdam, pp. 425-444, 1983.

P. Aliard, S. Belviso and B. C. Nguyen, Centre des Falbles Radioactivités, Laboratoire Mixte CNRS-CEA, 91190 Gif-sur-Yvette, France.

(Recelved October 14, 1985; revised December 2, 1985 ; accepted December 3, 1985.) 